\title{
Reiteration of Nitrogen Fixation Gene Sequences and Specificity of Rhizobium in Nodulation and Nitrogen Fixation in Phaseolus vulgaris
}

\author{
By ESPERANZA MARTÍNEZ,* MARCO A. PARDO, RAFAEL PALACIOS \\ AND MIGUEL ANGEL CEVALLOS \\ Centro de Investigación sobre Fijación de Nitrógeno, Universidad Nacional Autónoma de México, \\ Apdo. Postal 565-A, Cuernavaca, Morelos, Mexico
}

(Received 17 December 1984; revised 27 February 1985)

\begin{abstract}
We have previously reported that Rhizobium phaseoli has multiple copies of nitrogen-fixation gene sequences. In this work we extend our analysis to cover a broader range of $R$. phaseoli strains and other rhizobia isolated from different legumes. Our results indicate that most $R$. phaseoli strains have reiterated nifH sequences. Reiterations are also found in rhizobia from nodules of other Phaseolus species and from the close relative of Phaseolus, Pachyrhizus. However, nifH gene reiteration is not always found in the rhizobia able to nodulate and fix nitrogen in Phaseolus, since some strains isolated from nodules of Phaseolus vulgaris as well as from other legumes are able to establish an effective symbiosis with Phaseolus vulgaris and do not show reiterations. We propose that there are different evolutionary lines of $R$. phaseoli. The reiteration of nif genes may be considered a marker for the most abundant and specialized of these evolutionary lines.
\end{abstract}

\section{INTRODUCTION}

Bacteria of the genus Rhizobium induce nodules and fix nitrogen in the roots of legumes. Rhizobium species have been defined according to the host they infect. This classification gathers into a group different bacteria that may share only a certain nodulation ability. Rhizobium phaseoli, the symbiont of Phaseolus vulgaris, common bean, has been catalogued as a very heterogeneous group (Beynon \& Josey, 1980; Roberts et al., 1980; Catteau et al., 1984). We have described a peculiar organization of nitrogen fixation genes in $R$. phaseoli characterized by the presence of stable reiterations (Quinto et al., 1982). In $R$. phaseoli strain CFN-42, there are three different regions in its symbiotic plasmid that contain identical and complete nitrogenase reductase coding sequences ( $n i f H)$. Site-directed mutagenesis indicated that none of the three nif $H$ gene copies is indispensable for nitrogen fixation during symbiosis with Phaseolus vulgaris (Quinto et al., 1985). To establish how general nifH gene reiterations are in $R$. phaseoli, we extended our studies to strains isolated from diverse types of Phaseolus vulgaris and from other Phaseolus species. We analysed strains from different geographical origins with an emphasis on strains from Mesoamerica because Phaseolus vulgaris had its origin and was diversified in this region (Miranda, 1967; Gentry, 1969).

Reiterations of nif genes have been reported in bacteria other than rhizobia (Rice et al., 1982; Kallas et al., 1983; Scolnick \& Haselkorn, 1984). To understand further nif gene reiterations, and because of a possible correlation between the evolutionary trends of plant and Rhizobium, fastgrowing rhizobia were isolated from various legumes, the latter chosen because of their taxonomic relationships. In this paper we describe the symbiotic properties of these strains and analyse their nifH gene organization patterns. 


\section{METHODS}

Bacterial strains. $R$. phaseoli strains were isolated from bean nodules obtained from important native agricultural areas of Mexico: Jalisco, Hidalgo, Morelos and Guanajuato. $R$. phaseoli strains are listed in Table 1. Rhizobium strains from other legumes are listed in Table 2. To test for Agrobacterium contamination, all Rhizobium isolates were assayed for 3-ketolactose production (Bernaerts \& De Ley, 1963) using Benedict's reagent and cultures grown in BYLA medium. BYLA contained, per litre, $10 \mathrm{~g}$ lactose, $0.5 \mathrm{~g} \mathrm{~K}_{2} \mathrm{HPO}_{4}, 0 \cdot 1 \mathrm{~g} \mathrm{MgSO} \cdot 7 \mathrm{H}_{2} \mathrm{O}, 0 \cdot 2 \mathrm{~g}$ $\mathrm{CaCl}_{2}, 50 \mathrm{mg} \mathrm{FeCl}_{3} \cdot 6 \mathrm{H}_{2} \mathrm{O}, 3 \mathrm{~g}$ yeast extract and $15 \mathrm{~g}$ agar. None of the Rhizobium strains gave a positive reaction.

Isolation of Rhizobium strains. Bacteria were isolated from active nitrogen-fixing nodules from legumes growing in the field or grown from seeds in the laboratory in soils, and under conditions, that resembled their natural habitats. Nodules were surface sterilized and tested for surface contamination. Nodule isolates were grown in peptone/yeast medium, PY (Noel et al., 1984). Strains from Centrosema and Vigna, which do not grow well in PY, were grown in yeast/mannitol medium, YM (Vincent, 1970) that contained $1 \mathrm{~g}$ of yeast extract per litre. Isolated colonies were serially diluted in $10 \mathrm{~mm}-\mathrm{MgSO}_{4}, 0.01 \%(\mathrm{v} / \mathrm{v})$ Tween 40 (Kuykendall \& Elkan, 1976) and plated for further colony purification.

Nodulation assays. Seeds of different legumes were surface sterilized (Wacek \& Brill, 1976). Flasks of various sizes (depending on the size of the plants) were used, containing nitrogen-free plant nutrient solution (Wacek \&

Table 1. Rhizobium strains and pattern of nifH gene reiterations

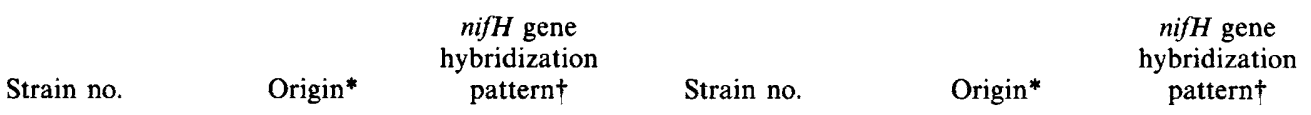

Strains isolated from cultivated Phaseolus vulgaris

\begin{tabular}{|c|c|c|c|c|}
\hline CFN 1 & I & Nitragin USA 8184 & Nitragin $^{a}$ & I \\
\hline CFN 2 & I & Nitragin USA 8251 & Nitragin $^{a}$ & I \\
\hline CFN 5 & I & Brazil 10 & Brazil & II \\
\hline CFN 6 & I & UMR 1020 & $\mathrm{Brazil}^{b}$ & - \\
\hline CFN 7 & I & UMR1026 & Brazilc & - \\
\hline CFN 10 & I & Viking 1 & $\mathrm{USA}^{d}$ & III \\
\hline CFN 17 & I & CIAT 896 & Colombia & II \\
\hline CFN 20 & I & CIAT 899 & Colombia & - \\
\hline CFN 22 & II & Brazil 281 & Brazile & II \\
\hline CFN 23 & I & \multirow{2}{*}{\multicolumn{3}{|c|}{ Strains from other legumes $\ddagger$}} \\
\hline CFN 25 & III & & & \\
\hline CFN 36 & I & CFN 226 & & II \\
\hline CFN 38 & II & CFN 227 & & I \\
\hline CFN 39 & $\mathrm{I}$ & CFN 238 & & IV \\
\hline CFN 42 & I & CFN 251 & & I \\
\hline CFN 44 & I & CFN 307 & & III \\
\hline CFN 81 & II & CFN 308 & & I \\
\hline CFN 88 & I & CFN 309 & & I \\
\hline CFN 90 & I & CFN 245 & & I \\
\hline CFN 272 & I & & & \\
\hline CFN 273 & I & & & \\
\hline CFN 276 & I & & & \\
\hline CFN 277 & I & & & \\
\hline CFN 278 & II & & & \\
\hline CFN 279 & II & & & \\
\hline CFN 280 & I & & & \\
\hline CFN 281 & 1 & & & \\
\hline CFN 283 & II & & & \\
\hline CFN 284 & II & & & \\
\hline CFN 275 & V & & & \\
\hline CFN 285 & IV & & & \\
\hline CFN 286 & IV & & & \\
\hline
\end{tabular}

* Unless otherwise indicated, strains were isolated by us, and were from Mexico. $a$, obtained from Nitragin Co., Milwaukee, Wis., USA ; $b, c$, obtained from Dr P. Graham, Dept of Soil Science, University of Minnesota St Paul, Minn., USA ( $b$ originally from Dr C. Vidor as C18 and $c$ originally from Dr T. Saito as CENA 183); $d$, obtained from Dr E. Schmidt, Dept of Soil Science, University of Minnesota; $e$, obtained from Dr J. Döbereiner, EMBRAPA, SNLCS, Rio de Janeiro, Brazil.

† Hybridization patterns are defined in Fig. 1 ; - only a single nifH hybridization band observed.

$\ddagger$ Includes strains from wild-type Phaseolus vulgaris. See Table 2 for original host plants. 
Table 2. Original hosts of Rhizobium strains isolated from legumes other than cultivated Phaseolus vulgaris

Strain no. Original host legume

CFN 225

Acacia albida

CFN 255

CFN 264

CFN 241

Centrosema pubescens

Crotalaria mollicula

CFN 231

Crotalaria pumila

CFN 232

Dalea leporina

Dalea leporina

CFN 233

CFN 242

CFN 243

Dalea leporina

Dalea leporina

CFN 249

Dalea leporina

Dalea leporina

CFN 265

Leucaena esculenta

CFN 234

CFN 244

CFN 246

Leucaena leucocephala

Macroptilium gibbosifolium

Medicago denticulata

CFN 245

Pachyrhizus erosus

CFN 226

CFN 227

CFN 251

CFN 238*

Phaseolus acutifolius

Phaseolus acutifolius

Phaseolus acutifolius

Phaseolus coccineus

CFN 307

Phaseolus vulgaris, wild-type

CFN 308

CFN 309

CFN 253

CFN 254

Phaseolus vulgaris, wild-type

Phaseolus vulgaris, wild-type

Vicia sativa

Vigna vexillata

* Obtained from Dr N. Amarger, Laboratoire de Microbiologie des Sols, INRA, Dijon, France, as DC 11 ; isolated in France.

Brill, 1976) and $0.8 \%(\mathrm{v} / \mathrm{v})$ agar. Inoculation was as described by Noel et al. (1984). Sometimes modified Leonard 'bottle jars' (Vincent, 1970) with vermiculite were used. All controls were devoid of nodules.

Acetylene reduction assays. Nitrogenase activity was measured by acetylene reduction (Wacek \& Brill, 1976). Whole root systems were incubated for $1 \mathrm{~h}$ in sealed $25 \mathrm{ml}$ vials containing $2 \%(\mathrm{v} / \mathrm{v})$ acetylene. Samples were injected into a Packard 430 gas chromatograph with a Poropak N 80-100 column.

DNA hybridization. DNA was obtained from the different Rhizobium strains and digested with BamHI restriction endonuclease. Total DNA digests were subjected to electrophoresis in $1 \%$ agarose gels and then transferred to nitrocellulose filters (Southern, 1975). Hybridization was performed under low stringency conditions, as reported previously (Quinto et al., 1982). A recombinant plasmid (pCQ152) carrying a $300 \mathrm{bp}$ sequence from the coding region of the $n i f H$ gene from $R$. phaseoli CFN-42 was used as probe; this fragment codes for amino acids 28 to 119 of nitrogenase reductase (Quinto et al., 1985).

\section{RESULTS}

Most $R$. phaseoli strains have nifH gene reiterations. Total DNA obtained from the strains isolated from Phaseolus vulgaris nodules was digested with BamHI. Total genomic digests were subjected to agarose gel electrophoresis, blotted and hybridized with a $n i f H$-specific probe from $R$. phaseoli CFN-42 (Quinto et al., 1985). The strains tested included bacteria from both bush Phaseolus vulgaris and climbing cultivars (the latter are considered to be better.nitrogen fixers: Graham, 1981), and from Phaseolus vulgaris wild-type. Fig. 1 shows the hybridization patterns of these strains. Pattern 1, with three bands of $9.8,5.6$ and $4.0 \mathrm{~kb}$ was the most common. We have also observed other triple-band patterns (Fig. 1, patterns II, III and IV) that have differences in the sizes of the bands. Pattern V shows only two bands.

In a first survey of 40 strains of $R$. phaseoli, only one did not show reiteration of $n i f H$. Since this strain, CIAT 899, is aluminium and acid tolerant, we investigated whether this type of $R$. phaseoli was common in acid soils. We analysed three other acid-tolerant strains; one of them (CIAT 896) showed reiterations, the others (UMR 1020 and UMR 1026) did not. UMR 1020, UMR 1026 and CIAT 899 each have the same size BamHI-generated nifH hybridization band.

nifH gene reiterations are found in bacteria isolated from other species of Phaseolus and from the close relative Pachyrhizus. Fig. 2 shows the taxonomic relationships of the legumes (Heywood, 1971) from which we isolated fast-growing strains of Rhizobium (Table 2). Emphasis was given 


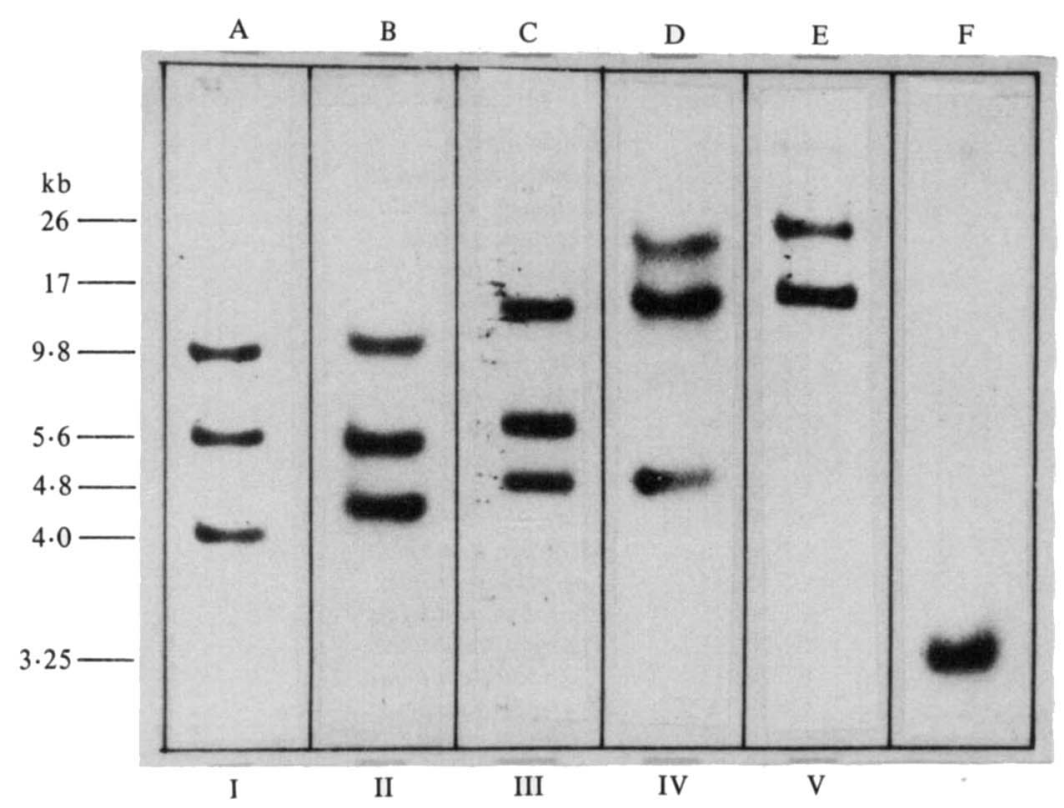

Fig. 1. Autoradiograms of Southern blots of BamHI-digested genomic DNA of different $R$. phaseoli strains after hybridization with a $300 \mathrm{bp}$ nifH internal sequence from $R$. phaseoli CFN 42. Hybridization patterns I to $\mathrm{V}$ are defined by the sizes of the fragments. Strains: A, CFN 42; B, CFN 279; C, CFN 25; D, CFN 285; E, CFN 275; F, CIAT 899.

to the isolation of bacterial strains from plants related to Phaseolus vulgaris (Marechal et al., 1978). Strains from Phaseolus coccineus, Phaseolus acutifolius and from Pachyrhizus nodules showed reiterated nifH sequences and were able to nodulate and fix nitrogen in Phaseolus vulgaris (Fig. 2). The patterns of reiteration fall within the patterns obtained for $R$. phaseoli strains (Table 1). No reiterations were found among Rhizobium strains from other legumes including some Phaseolus relatives such as Vigna and Macroptilium.

The capacity to nodulate $P$. vulgaris effectively is widespread among rhizobia. Various strains from different legumes were able to nodulate and fix nitrogen in Phaseolus vulgaris; this capacity did not correlate with the taxonomic position of the legumes from which the bacteria were isolated (Fig. 2). Strains isolated from the subfamily Mimosoideae, from the genera Leucaena and Acacia, were able to nodulate Phaseolus vulgaris. Furthermore, strains from Leucaena leucocephala and L. esculenta were able to fix nitrogen in Phaseolus vulgaris. In contrast, strains from Vigna, which belongs to the same subtribe as Phaseolus, formed only small ineffective nodules from which bacteria could not be recovered.

Non-specific strains that are able to fix nitrogen in bean do not have reiterated nif sequences. Strains isolated from Macroptilium gibbosifolium, Crotalaria pumila, Dalea leporina, Leucaena leucocephala and L. esculenta established effective nodules in Phaseolus vulgaris, did not show reiterated sequences when probed with a $R$. phaseoli internal nifH fragment, and displayed different hybridization patterns that distinguished them from each other (Fig. 3). When reisolated from Phaseolus vulgaris nodules, the strains proved to be the same as the inoculum by the nif hybridization pattern (Fig. 3), the total DNA digestion pattern, and the ability to nodulate the original host legume (data not shown). The nitrogen-fixing activities of these strains in Phaseolus vulgaris, measured by the acetylene reduction assay, were in some cases similar to those of the $R$. phaseoli strains (data not shown).

'Non-reiterated' $R$. phaseoli strains have a broad infection spectrum. We tested the symbiotic properties of different Rhizobium strains using Leucaena leucocephala as a host. L. leucocephala has been described as specific for its Rhizobium requirements (Norris, 1967; Trinick, 1968). 


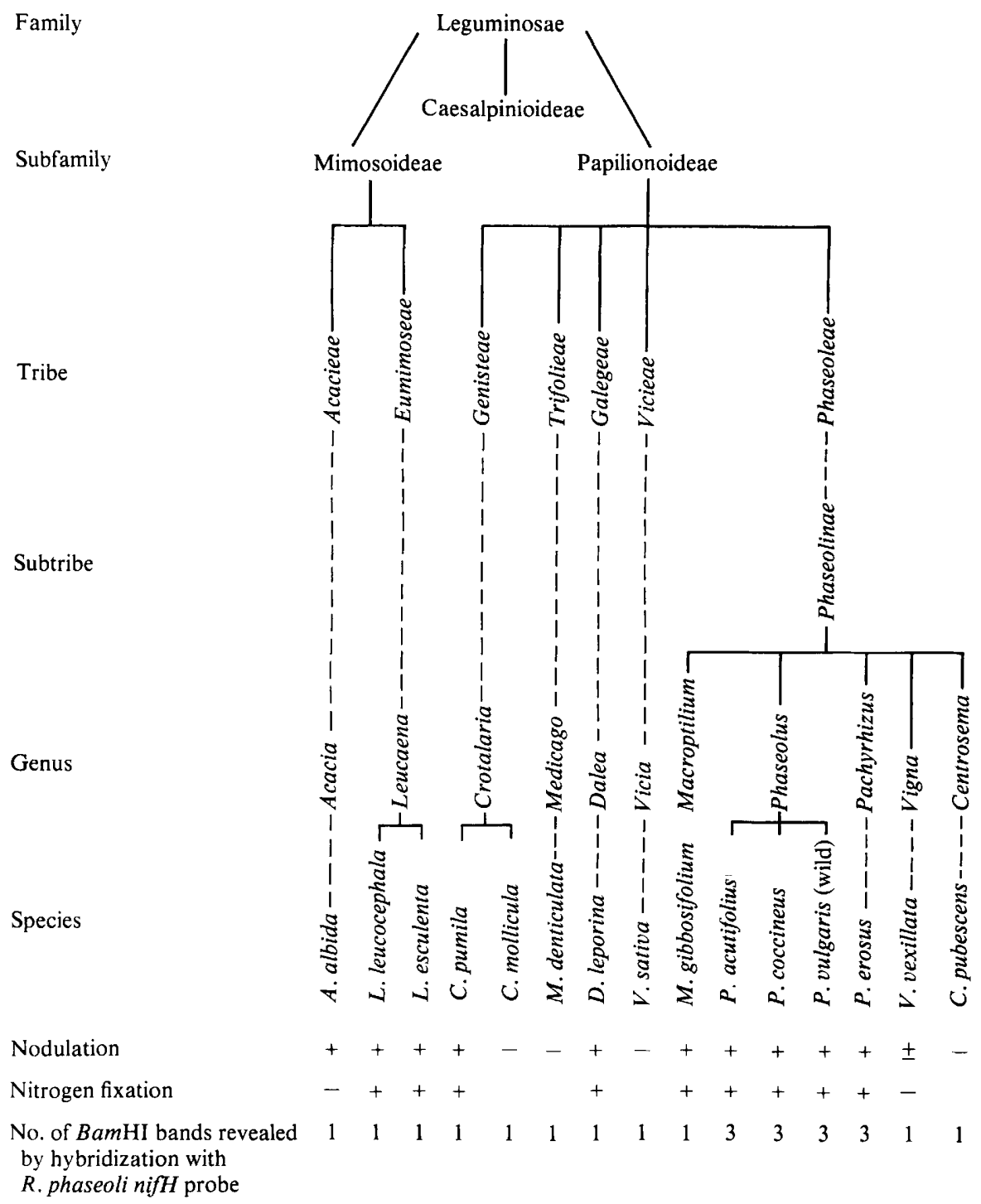

Fig. 2. Nodulation and nitrogen fixation in Phaseolus vulgaris, and nifH reiterations in rhizobia isolated from various legumes, whose taxonomic relations are shown.

'Non-reiterated' $R$. phaseoli strains, nodulated $L$. leucocephala, although not effectively: CIAT 899 (M. Megias, unpublished observation), UMR 1020 and UMR 1026, (this study). None of the 'nifH-reiterated' $R$. phaseoli strains we tested (CFN 1, CFN 5, CFN 23, CFN 25, CFN 42) nodulated L. leucocephala. The non-specific Rhizobium strains that nodulated and fixed nitrogen in Phaseolus vulgaris (strains from Dalea leporina, Crotalaria pumila and Macroptilium gibbosifolium) nodulated $L$. leucocephala effectively, and may be considered broad-host-range strains. These strains showed single nifH hybridization bands.

Under natural conditions Phaseolus vulgaris may be nodulated by strains that nodulate other legumes. To test whether Rhizobium from other legumes could nodulate Phaseolus vulgaris under natural conditions, we grew beans in soils where wild or cultivated Leucaena trees grew. We isolated 12 strains from these bean nodules. About half of these strains were able to nodulate $L$ leucocephala effectively and did not have reiterations of nifH (Fig. 4); the other isolates only nodulated bean and had the reiterated pattern of $R$. phaseoli (Fig. 4). 


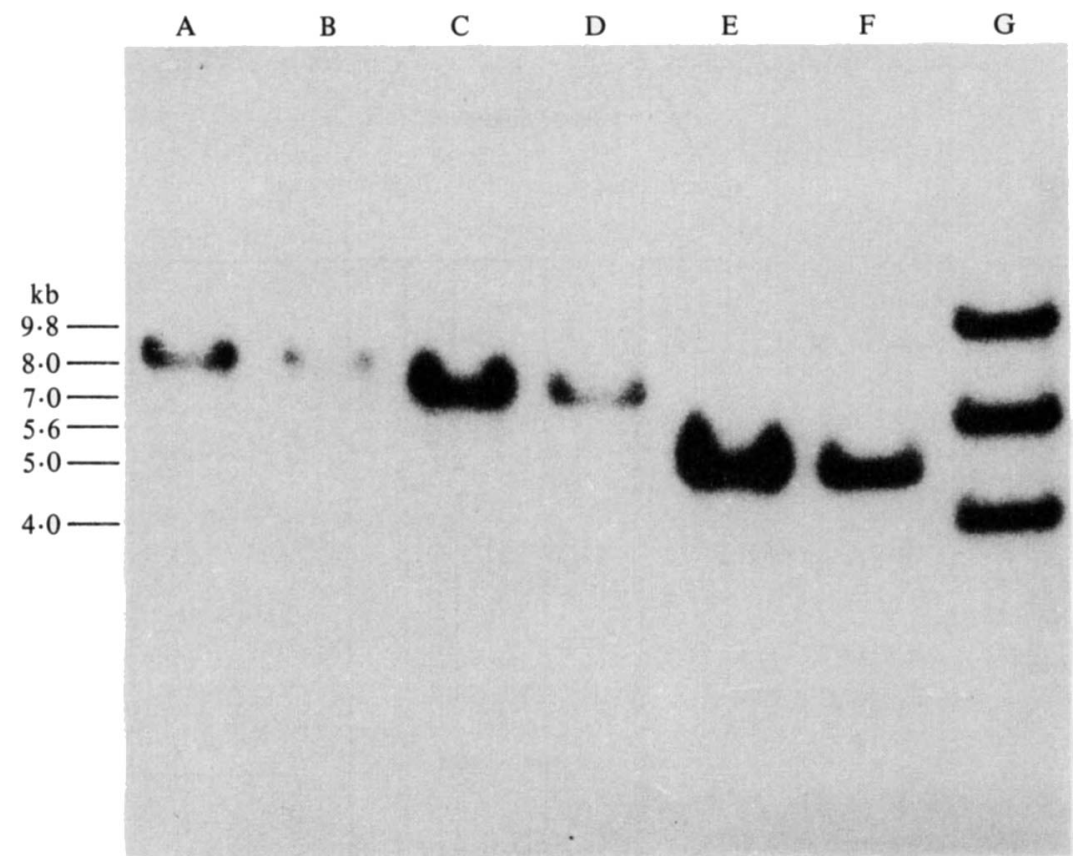

Fig. 3. Autoradiograms of Southern blots of BamHI-digested genomic DNA of different Rhizobium strains hybridized with a $300 \mathrm{bp}$ nifH internal sequence from $R$. phaseoli CFN 42. A, CFN 241 (from Crotalaria pumila); B, CFN 241 after reisolation from bean nodules; C, CFN 249 (from Dalea leporina); D, CFN 249 after reisolation from bean nodules; E, CFN 243 (from Dalea leporina); F, CFN 243 after reisolation from bean nodules; G, CFN 42, reference $R$. phaseoli strain.

\section{DISCUSSION}

$R$. phaseoli has been defined as the Rhizobium that forms nitrogen-fixing nodules in Phaseolus vulgaris. It comprises a very heterogeneous group on the basis of protein patterns (Roberts et al., 1980), plasmid profiles (Martínez \& Palacios, 1984), antibiotic resistance (Beynon \& Josey, 1980) and numerical taxonomy (Catteau et al., 1984). Our results indicate that it is a more homogeneous group on the basis of nif gene reiterations. In $R$. phaseoli strain CFN 42, the three copies of nifH are part of a large $270 \mathrm{MDal}$ plasmid (Quinto et al., 1982) that also carries other symbiotic determinants (unpublished). Thus the reiterated nif genes are linked to the symbiotic information for bean nodulation as part of a plasmid that could be contained in different bacterial backgrounds. We have observed that randomly selected cloned fragments from the $R$. phaseoli CFN 42 symbiotic plasmid show a higher degree of conservation than cloned chromosomal fragments from the same strain when hybridized to total genome digests from other $R$. phaseoli strains (unpublished results).

Our screening of fast-growing rhizobia from different legumes of the subfamilies Papilionoideae and Mimosoideae was not intended to be comprehensive. R. leguminosarum and $R$. trifolii were not included, as their nifH gene organizations have already been established (Ruvkun \& Ausubel, 1980). Our results suggest that reiterations of the nifH gene are restricted to rhizobia isolated from some genera of the tribe Phaseolineae. Results from other groups support this proposal. Strain ANU 240, a streptomycin-resistant derivative of NGR 234, has two nifH copies (Morrison et al., 1983). This broad-host-range strain (Broughton et al., 1984) was originally isolated from Lab-lab purpureus which belong to the tribe Phaseolineae. Strain NGR 234 does not nodulate Phaseolus vulgaris (Trinick, 1980). Recently, reiterations of nif genes have been reported in fast-growing $R$. japonicum (Prakash \& Atherly, 1984); Glycine max, its host, also belongs to the tribe Phaseolineae. We have tested these $R$. japonicum strains for nodulation in Phaseolus vulgaris, and have found that they form small ineffective nodules.

Nodulation of Phaseolus vulgaris by a wide range of strains from tropical legumes was reported 


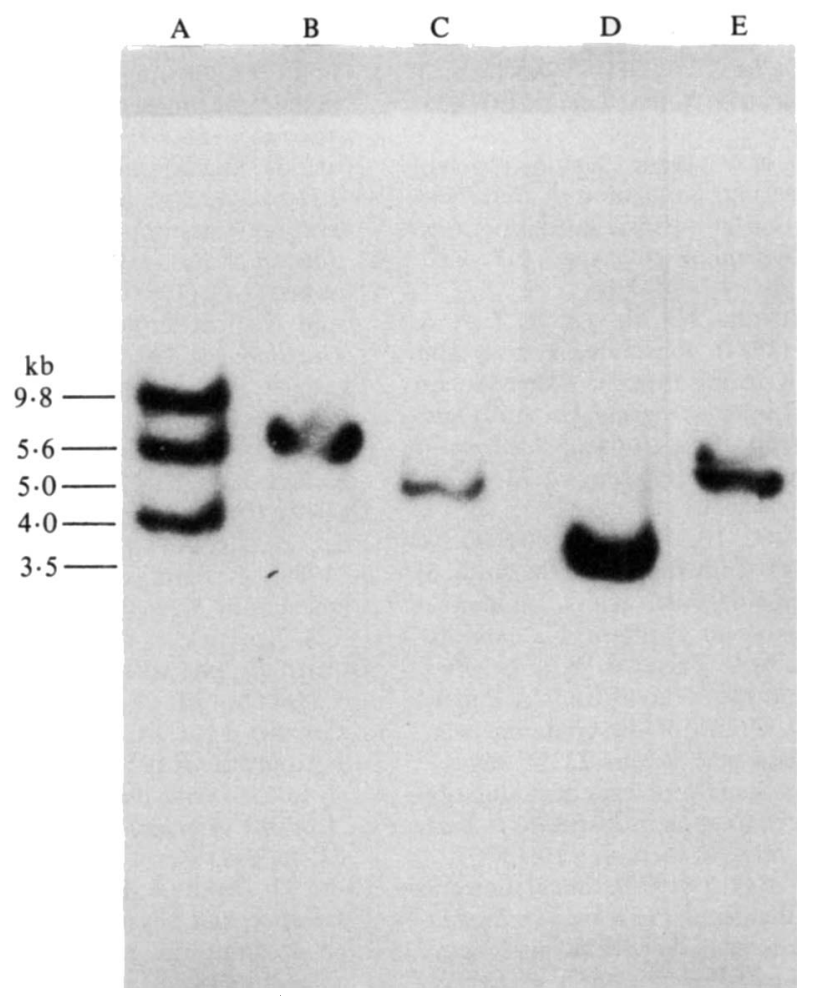

Fig. 4. nifH gene hybridization patterns of five strains of Rhizobium isolated from nodules of Phaseolus vulgaris grown in soils where Leucaena spp. grew. A, CFN 313 (this strain behaves like other "nifHreiterated' $R$. phaseoli); B, CFN 288; C, CFN 289; D, CFN 311; E, CFN 290 (these strains resemble Leucaena symbionts in their ability to nodulate $L$. leucocephala and in having only a single copy of nifH).

by Lange (1961), but there were no data on the nitrogen fixation activity. Our results show that Phaseolus vulgaris may be nodulated effectively by non-specific Rhizobium strains from tropical legumes. These strains do not show nif reiterations. We propose that those strains isolated primarily as $R$. phaseoli and that do not have nif reiterations may be representatives of fastgrowing rhizobia from tropical legumes that are capable of nodulating Phaseolus vulgaris. Indeed, we have found Leucaena Rhizobium strains forming nodules on bean roots in soils where Leucaena trees grow.

Rhizobium strains from Dalea leporina, Crotalaria pumila and Macroptilium gibbosifolium, besides nodulating their original host, also nodulate Phaseolus and Leucaena effectively. $R$. phaseoli strains CIAT 899, UMR 1020 and UMR 1026 also nodulate Leucaena. In contrast, $R$. phaseoli 'nif $H$-reiterated' strains are more specific, nodulating effectively only Phaseolus vulgaris (cultivar and wild-type) and Phaseolus coccineus (data not shown; Graham \& Halliday, 1977). If the primitive Rhizobium had a broad host range and evolved to become more specific for certain legumes, then the nifH gene reiterations may be considered a marker of this specialization in one of the evolutionary trends of $R$. phaseoli.

The authors wish to thank Lorenzo Segovia and Jean Marc Bonneville for critically reading the manuscript. The taxonomic classification of legumes was performed in the Herbario MEXU of the Institute of Biology, University of Mexico. Partial financial support for this research was provided by the US National Academy of Sciences/National Research Council by means of a grant from the US Agency for International Development, and by grants from the Consejo Nacional de Ciencia y Technología and the Fondo de Estudios e Investigaciones Ricardo J. Zevada. 


\section{REFERENCES}

Bernaerts, M. J. \& De Ley, J. (1963). A biochemical test for crown gall bacteria. Nature, London 197, 406407

Beynon, J. L. \& Josey, D. P. (1980). Demonstration of heterogeneity in a natural population of Rhizobium phaseoli using variation in intrinsic antibiotic resistance. Journal of General Microbiology 118, 437442.

Broughton, W. J., Heycke, N., Meyer, H. Z. A. \& Pankhurst, C. E. (1984). Plasmid-linked nif and "nod" genes in fast-growing rhizobia that nodulate Glycine max, Psophocarpus tetragonolobus and Vigna unguiculata. Proceedings of the National Academy of Sciences of the United States of America 72, 36283632.

Catteau, M., Khanaka, H., Legrand, M. D. \& Guillaume, J. (1984). Contribution to the study of Rhizobium and Agrobacterium genus: numerical taxonomy. In Advances in Nitrogen Fixation Research, p. 330. Edited by C. Veeger \& W. E. Newton. The Hague \& Wageningen: Nijhoff, Junk \& Pudoc.

Gentry, H. S. (1969). Origin of the common bean, Phaseolus vulgaris. Economic Botany 23, 55-69.

Graham, P. H. (1981). Some problems of nodulation and symbiotic nitrogen fixation in Phaseolus vulgaris L: a review. Field Crops Research 4, 93-112.

GraHAM, P. H. \& HallidaY, J. (1977). Inoculation and nitrogen fixation in the genus Phaseolus. In Exploiting the Legume-Rhizobium Symbiosis in Tropical Agriculture (University of Hawaii College of Tropical Agriculture, Miscellaneous Publication no. 145), pp. 313-334. Edited by J. M. Vincent.

HeYwood, V. H. (1971). The Leguminosae. A systematic purview. In Chemotaxonomy of the Leguminosae, pp. 1-29. Edited by J. Harborne, D. Boulter \& B. L. Turner. New York: Academic Press.

Kallas, T., Rebière, M. C., RippKa, R. \& Tandeau DE MARSAC, N. (1983). The structural nif genes of the cyanobacteria Gloethece sp. and Calothrix sp. share homology with those of Anabaena sp., but the Gloethece genes have a different arrangement. Journal of Bacteriology 155, 427-431.

KuYKendall, L. D. \& ElKan, G. H. (1976). Rhizobium japonicum derivatives differing in nitrogen fixing efficiency and carbohydrate utilization. Applied and Environmental Microbiology 32, 511-519.

LANGE, R. T. (1961). Nodule bacteria associated with the indigenous Leguminosae of South-Western Australia. Journal of General Microbiology 26, 351359.

Marechal, R., Masherpa, J. M. \& Stainer, F. (1978). Étude du complexe Phaseolus-Vigna (Papilionaceae). Boissiera 28, 1-273.

Martínez, E. \& Palacios, R. (1984). Is it necessary to improve nitrogen fixation of bean in agricultural fields in México? In Advances in Nitrogen Fixation Research, p. 60. Edited by C. Veeger \& W. E. Newton. The Hague \& Wageningen: Nijhoff, Junk \& Pudoc.

Miranda, C. S. (1967). Origen de Phaseolus vulgaris L. Agrociencia 1, 99-109.

Morrison, N. A., HaU, C. Y., Trinick, M. J., Shine, J. \& Rolfe, B. (1983). Heat curing of a Sym plasmid in a fast-growing Rhizobium sp. that is able to nodulate legumes and the nonlegume Parasponia sp. Journal of Bacteriology 153, 527-531.

Noel, K. D., Sánchez, F., Fernández, L., Leemans, J. \& Cevallos, M. A. (1984). Rhizobium phaseoli symbiotic mutants with transposon Tn5 insertions. Journal of Bacteriology 158, 148-155.

NORRIS, D. O. (1967). The intelligent use of inoculation and lime pelleting for tropical legumes. Tropical Grasslands 1, 107-121.

Prakash, R. K. \& Atherly, A. G. (1984). Reiteration of genes involved in symbiotic nitrogen fixation by fast-growing Rhizobium japonicum. Journal of Bacteriology 160, 785-787.

Quinto, C., DE la Vega, H., Flores, M., Fernández, L., Ballado, T., Soberón, G. \& Palacios, R. (1982). Reiteration of nitrogen fixation gene sequences in Rhizobium phaseoli. Nature, London 299 , 724-726.

Quinto, C., De la Vega, H., Flores, M., Leemans, J., Cevallos, M. A., Pardo, M. A., Azpiroz, R., Girard, M. L., Calva, E. \& Palacios, R. (1985). Nitrogenase reductase: a functional multigene family in Rhizobium phaseoli. Proceedings of the National Academy of Sciences of the United States of America 82, 1170-1174.

Rice, D., Mazur, B. J. \& Haselkorn, R. (1982). Isolation and physical mapping of nitrogen fixation genes from the cyanobacterium Anabaena 7120 . Journal of Biological Chemistry 257, 13157-13163.

Roberts, G., Leps, W. T., SILver, L. E. \& Brill, W. J. (1980). Use of two-dimensional polyacrylamide gel electrophoresis to identify and classify Rhizobium strains. Applied and Environmental Microbiology 39, 414 422 .

Ruvkun, G. B. \& Ausubel, F. M. (1980). Interspecies homology of nitrogenase genes. Proceedings of the National Academy of Sciences of the United States of America 78, 229-233.

Scolnick, P. A. \& Haselkorn, R. (1984). Activation of extra copies of genes coding for nitrogenase in Rhodopseudomonas capsulata. Nature, London 307, 289-292.

SOUTHERN, E. M. (1975). Detection of specific sequences among DNA fragments separated by gel electrophoresis. Journal of Molecular Biology 98, 503-517.

TRINICK, M. J. (1968). Nodulation of tropical legumes. 1. Specificity in the Rhizobium symbiosis of Leucaena leucocephala. Experimental Agriculture 4, 243-253.

TRINICK, M. J. (1980). Relationships amongst the fastgrowing Rhizobia of Lab-lab purpureus, Leucaena leucocephala, Mimosa spp., Acacia farnesiana and Sesbania grandiflora and their affinities with other rhizobial groups. Journal of Applied Bacteriology 49, 39-53.

VinCENT, J. M. (1970). A Manual for the Practical Study of the Root-Nodule Bacteria (International Biological Programme Handbook, vol. 15). Oxford \& Edinburgh: Blackwell Scientific Publications.

W ACEK, T. \& BRILL, W. J. (1976). Simple, rapid assay for screening nitrogen fixing ability in soybean. Crop Science 16, 519-522. 